\title{
"My heart sang within me, and I was glad to be dead": The Reception of Near-Death Experiences Across the Cultures of Oceania
}

\author{
Gregory Shushan, $\mathrm{PhD}$ \\ University of Wales Trinity Saint David
}

\begin{abstract}
A comparative survey of how near-death experiences (NDEs) intersected with afterlife myths and shamanic practices, as reported in the mid-19th to mid-20th century by missionaries, explorers, and ethnographers of Polynesia, Melanesia, Micronesia, and Australia, reveals various culturally distinct patterns. In Polynesia and Melanesia, documentary accounts of NDEs are found alongside myths and beliefs that directly refer to the phenomenon. In contrast, in Australia and Micronesia NDEs are almost entirely absent, and afterlife journey myths instead typically have shamanic contexts. I argue that these dynamics can be explained by reference to certain religious and cultural particularities, including differences in burial practices, variations in attitudes towards the dead, and diversity of shamanic traditions.
\end{abstract}

KEY WORDS: Oceanic traditional religions, near-death experience, afterlife beliefs, shamanism, culture, experiential source hypothesis

\footnotetext{
Gregory Shushan, PhD, is Honorary Research Fellow in the Religious Experience Research Centre, University of Wales Trinity Saint David. He was previously Research Fellow at the Ian Ramsey Centre for Science and Religion, University of Oxford; and at the Centro Incontri Umani (The Cross Cultural Centre) at Ascona, Switzerland. He holds degrees in Religious Studies (University of Wales Lampeter) and in Research Methods for the Humanities, Egyptian Archaeology, and Eastern Mediterranean Archaeology (University of London). He has lectured at universities in the UK, Ireland, and Switzerland and has presented his research in seven countries. His website is www.gregoryshushan.com. The present article is part of a larger research project (Shushan, 2018) made possible by a generous grant from the Perrott-Warrick Fund, Trinity College Cambridge, with additional support from the Cedar Creek Institute and from the Society for Psychical Research. Dr. Shushan also thanks the International Association for Near-Death Studies (IANDS) Research Fund for assistance with preparation of this article. Correspondence regarding this article should be sent to Dr. Shushan at e-mail: g.shushan@uwtsd.ac.uk.
} 
In this paper, I explore how near-death experiences (NDEs) were received in the indigenous religions of Polynesia, Micronesia, Melanesia, and Australia. Rather than culture, ancestry, or history, the divisions between these four regions are based on geography. Only Australia and Polynesia can be considered actual cultural/ethnic categories, for there are "at least six widely different ethnic units" in Micronesia and "hundreds" in Melanesia (Oliver, 2002, p. 2).

Nevertheless, there are some pan-regional similarities of afterliferelated beliefs, including that the soul could temporarily leave the body during illness or through shamanic practices and that apparently dead individuals might be in a trance from which they could awaken. It was commonly accepted that souls left the body after death, remained for a time near the corpse, then traveled via the rising or setting sun or through caves, holes, or volcanoes. They encountered various guardian, gatekeeper, interrogator, and judge figures, and underwent ordeals or tests. The other world was situated on a distant island or mountain, in the sky, or under a lake or the ocean. Admission was determined by rank, wealth, virtue, mode of death, or proper funerary rites. Social status was maintained, though in some cases the unworthy went to less favorable realms or were annihilated (Moss, 1925, pp. 89, 112, 118-131).

Spirits could continue to influence the living in either helpful or harmful ways, either from the other world or as ghosts on Earth. The notion of ultimately merging "into an undifferentiated company of 'ancestors' or some even more inclusive category of spirit beings" (Oliver, 1989 , p. 771) was also widely attested. Less common were beliefs in reincarnation and that the soul died with the body, and in many cases there was simply little interest in afterlife speculations (Oliver, 1989, pp. 132-133, 153).

An important consideration in an exploration of the type represented in this paper is the degree to which sources reflect indigenous culture versus exogenous influences such as religious conversion. The primary conversion religion of Oceania is Christianity. However, Christianity was relatively slow to take root in Oceania, beginning as late as the mid-20th century in some regions (Ernst \& Anisi, 2016, p. 591). Thus in undertaking this exploration, I conducted an exhaustive search of available primary sources published prior to wide-scale conversion: accounts of early missionaries, explorers, and ethnographers from the mid-19th to mid-20th centuries. The search yielded numerous accounts of NDEs and related beliefs, which I organized into region and present below as culturally contextualized summary overviews. I then 
provide a phenomenological comparison of how NDEs were received across the different cultures.

It should be noted that given the religious and political contexts of the missionary and explorer accounts, they are sometimes marred by attendant agendas and ethnocentricities. Such biases do not, however, always indicate inadequate reporting, and indeed many of the descriptions found in these sources were later confirmed by anthropologists. The fact that these accounts attest to knowledge of NDEs well over a century before the phenomenon was popularized in the West also indicates a degree of reliability.

My syntheses of the accounts are sometimes drawn from a wide range of pages in the primary sources, combining summaries with a free use of quotations. For greater readability I have departed from conventional American Psychological Association formatting, and rather than citing each page number separately I provide the entire page range of the primary source at the beginning or end of paragraphs.

\section{Polynesia}

Polynesian "song and myth delight in recounting the adventures of those who have visited spirit-world" (Gill, 1877, p. 3). Such visits were said to bring new knowledge and transformation, from the restoration of sight in the blind to the discovery of fire (Williamson, 1933, vol. II, pp. 190-195, 200, 205).

In Hawai'i, information about the afterlife originated with people "who have been brought back to life from the dead" (Keauokalini, 1860/1932, p. 48). Accounts of their NDEs were elaborated upon over time, and accepted as divine teachings (Jarves, 1843, pp. 42-43). NDEs could occur when helpful ancestor spirits "bring back the spirit and restore life to the body":

Many people who had died and come to life again ... even some people of this age, who have swooned or perhaps lain dead for a few hours or half a day, have related their [afterlife] experiences. . . . The reason they were believed in was because so many had died and come to life again and had told innumerable stories about these places (Kamakau, 1866-71/1964, pp. 47-49).

The last king of the Kingdom of Hawai'i, David Kalakaua (1888), wrote that Po, the underworld, "could be visited by favored mortals, and the dead were sometimes brought back from it to earth" (p. 39). American missionaries noted that "various accounts have appeared 
in print ... of the adventures of spirits, who after a protracted stay among the spirits of the dead, have been forced back into their bodies to resume active life among the living" (Emerson, 1902, pp. 13-14). Missionaries also cited beliefs that souls could be "driven back into the body by other ghosts, or persuaded to come back through offerings or incantations given by living friends, so that a dead person could become alive again" (Westervelt, 1915, p. 248). In his exhaustive survey, James Frazer (1922, pp. 428-429) confirmed that "when persons recovered from a death-like swoon, it was supposed that their souls had gone to the underworld and been sent back to earth by [underworld deity] Milu" or by a family's guardian deity. Food was often left near bodies in case the soul returned, and graves were not prepared until it was certain that it would not (Green \& Beckwith, 1926, p. 181).

In an account from Kuala (Hawai'i) reported by German ethnologist Adolf Bastian in 1833, a man died but revived after eight days. He told his family that he had been to a pleasant realm of light and abundance, ruled by Milu who chose the souls of the most beautiful women for his wives. Souls of the dead retained the bodily conditions they had at death, whether young, old, or ill (Frazer, 1922, pp. 428-429).

A more detailed 19th century NDE is that of a Kona woman named Kalima (Haley, 1892/1907, pp. 83-85; cf. Kellehear, 2001). As her family and friends mourned at her funeral, near her "rigid form and ashen face," Kalima suddenly breathed and opened her eyes. After recovering, she recounted her experience:

I died, as you know. I seemed to leave my body and stand beside it, looking down on what was me. The me that was standing there looked like the form I was looking at, only, I was alive and the other was dead. I gazed at my body for a few minutes, then turned and walked away. I left the house and village, and walked on and on to the next village, and there I found crowds of people ...

Though this was apparently an earthly village, it was much larger than the one she knew, with many houses and people of all ages.

Some of them I knew and they spoke to me-although that seemed strange, for I knew they were dead-but nearly all were strangers. They were all so happy! They seemed not to have a care; nothing to trouble them. Joy was in every face, and happy laughter and bright, loving words were on every tongue.

Kalima passed through more villages, meeting people she had known in life, and "felt so full of joy, too, that my heart sang within me, and I was glad to be dead." Feeling "happier every minute," she 
proceeded to a large village near Pele's volcano-a barren area in earthly reality. She was greeted cheerfully but told, "You must go back to your body. You are not to die yet."

I did not want to go back. I begged and prayed to be allowed to stay with them, but they said, "No, you must go back; and if you do not go willingly, we will make you go."

Kalima wept and resisted, but was ultimately forced to return the way she had come. The people in the villages turned against her and drove her back to her lifeless body.

I looked at it and hated it. Was that my body? What a horrid, loathsome thing it was to me now, since I had seen so many beautiful, happy creatures! Must I go and live in that thing again?

She refused to re-enter the body, so the spirits pushed her "head foremost into the big toe." Her "body came to life again, and I opened my eyes." According to Mrs. E. N. Haley (1892/1907, p. 85) who reported the NDE, Kalima never varied her account, "and never ceased to regret coming back to her body" and being forced to leave the joy she had experienced in the other world. According to beliefs on Oahu, when a body grows cold during a near-death state, "it becomes difficult to force the reluctant spirit to reenter," and a shaman would coax it under the nail of the big toe (Emerson, 1902, pp. 13-14).

In a narrative from Maui (Westervelt, 1915, pp. 100-107), a man named Ka-ilio-hae died from an illness but revived and "told his family all about his wonderful journey to the land of ghosts." His soul left his body through his left eye, and looking back, the body appeared like a great mountain with eyes like dark caves. Suddenly afraid, Kailio-hae went to the rooftop but was disturbed by the sound of people mourning him, so he flew away towards spirit world. His deceased sister met him at the entrance and took him to her house but warned him not to enter or eat anything if he hoped to return to Earth. They proceeded to "the place of whirlwinds"-a hill where spirits danced and played-then to Walia, "the high chief of ghosts." After successfully clearing obstacles intended to test one's religious knowledge and devotion, they finally met Walia. Ka-ilio-hae told Walia the history of his people and was then informed that he must "go back and enter his body and tell his people about troubles near at hand," or else be thrown to Milu. A beautiful woman gave Ka-ilio-hae directions home, and although he was reluctant to leave, his sister forced him, for she had "the power of sometimes turning a ghost back to its body again." 
When he saw his body he felt "very much afraid" and was repulsed by the smell. He tried to escape, but his sister pushed him in through the foot.

In a 19th century legend from Oahu (Rice, 1923, pp. 126-132), a farmer named Makua was swallowed by a fish and taken to the land of the deity Kane. Two deities explained to him that if he successfully completed a series of trials, he could remain in that beautiful realm of joy and abundance and become a god himself. If he failed, he would return to Earth as "a messenger and will tell to men the beauties of this land." After meeting his deceased family members, he ultimately failed a test by weeping when he thought his spirit wife had drown.

Suddenly a very dazzling light shone ... . Makua saw that the heavens were open and he beheld two bodies clothed in light and accompanied by many spirits arrayed in glorious raiment, but with sorrowful countenances. The spirits spoke, saying, "Dust to dust," and then the doors of the heavens closed.

Makua wandered through the woods to the seashore where the giant fish took him home, and he told his people what had happened to him.

Legends such as those of Ka-ilio-hae and Makua seem to be midway between actual NDEs and myths, suggesting a stage in the mythologizing process. Such accounts involved culture-heroes from the distant past rather than recent individuals. In contrast, the historicity of Kalima is not in doubt, and her narrative is more consistent with NDEs from other parts of the world.

Hawaiian afterlife beliefs sometimes had shamanic origins. People of Ka'awaloa village knew about the otherworld from the dreams and visions of shamans. Echoing NDEs, these beliefs included meeting deceased relatives, meeting a being of light, and traveling to a heavenly realm before returning to Earth to watch over their people (Ellis, 1823/1917, p. 107).

There are also numerous examples of "Orpheus"-type myths in which an individual in the midst of intense mourning travels to the other world in order to retrieve a recently deceased loved one and bring him or her back to Earth—and thus back to life (e.g., Emerson, 1902, pp. 66-68, 712-714; Fornander, 1918-19, p. 188; Kamakau, 186671/1964, pp. 51-52). These myths recall the shamanic practice of soulretrieval-traveling to the otherworld to rescue a soul in danger of death. Some myths had overt shamanic contexts, involving shamans assisting the mourning individuals on their mission. In one example, a shaman told Hiku how to retrieve his deceased wife Kawelu. Hiku 
descended to the underworld on a vine, but when he found Kawelu she was reluctant to return with him because of his bad smell. Though she eventually agreed, when they returned to Earth she refused to enter her body because it had begun to decay. Hiku eventually succeeded in coaxing her back in and restoring her to life (Fornander, 1918-19, pp. 186ff).

In the Society Islands, people believed to be dead sometimes revived, "and after returning to consciousness confirmed the statements about the Po, which they believed they had seen." In one example, a man named Pupu-te-tipa "was once taken bodily by the gods down into the Po and kept several days, but at last for the sake of his family was released and returned home" (Henry \& Orsmond, 1928/1971, p. 202).

In a mid-19th century NDE from Raiatea, a woman named Terematai revived after days of unconsciousness, claiming that she had "been to heaven" where she saw both Raiateans and Europeans she recognized. She concluded, "I wished to remain but God sent me back to exhort my family that they may be saved." She was described as being "in a very happy state of mind and appeared wholly absorbed in spiritual subjects" (Gunson, 1962, p. 218).

Another mid-19th century NDE, from the island of Huahine, involved an elderly queen who "visited the other world" while in a cataleptic trance. When she revived, "she told her friends that, when there, she glided about among numerous people whom she had formerly known." They communicated with her telepathically and could pass through each other in a "bodiless state." She returned to Earth, for "by order of a spirit she had to enter again into her body, though it was in a state of corruption" (Williamson, 1933, vol. I, p. 373).

Robert Louis Stevenson (1891/1896, pp. 215-216) recounted the legend of a princess who died and went to Raiatea, where a spirit forced her to climb trees and collect coconuts for him. She was discovered by a spirit-relative who took her back to Tahiti "where she found her body still waked, but already swollen with the approaches of corruption." When she saw the horrifying sight, she prayed to remain dead, though the spirit compelled her to enter via "the least dignified of entrances, and her startled family beheld the body move."

Towards the end of the 19th century, "the last queen of Tahiti" returned to her body "many days" after her death. Upon revival, she described "the departure of her soul through the air to Paradise and ... its subsequent unwilling return to its putrefying body in obedience to the command of a chief who appeared to reign in the world of happy 
souls that she had gone to." The chief forced her to return in order facilitate his own forthcoming reincarnation, by becoming her lover. He instructed her not to convert to Christianity, but when she was forced to do so by some authority, the chief was unable to complete his reincarnation (Handy, 1927, pp. 85-86).

Tahitian afterlife beliefs also incorporated knowledge of NDEs. Three days after leaving the body some souls would land on the Stone of Life, and the deity Tu-ta-horoa "would under certain conditions tell it to return to its body to remain a while longer in this life." Those who landed on the Stone of Death proceeded to a spirit realm, and the body on Earth died. NDEs are also evident in Tahitian Orpheus myths, such as that of the deceased moon goddess, Hina. Her husband, Tafa'i, attempted to catch her at "the last place whence spirits could be recalled to this world." Though she was reluctant to return, Tafa'i succeeded in bringing her back to Earth where she "re-entered her body, which was still well-preserved, and opened her mortal eyes," to the joy of her people (Henry \& Orsmond, 1928/1971, pp. 563-564).

In Cook Islands afterlife beliefs, souls of the dead sometimes met friendly spirits who told them, "Go back and live" and sent them back to "re-inhabit the once-forsaken body" (Gill, 1876, pp. 160-161, 221-224). A number of myths and legends also had NDE contexts and themes. In a Rarotonga example, a woman named Akimano had such an intense sexual experience "that her spirit departed from her body and went up to the god Tiki." When Tiki learned of her cause of death, he refused her entrance to his realm, telling her, "There is no place here for those who have died that death." He made her return to Earth, and "the spirit of the woman returned again to its body and so came to life again." An Aitutaki myth told of a man named Tekauae who traveled to the underworld while near death. After avoiding eating a bowl of live centipedes, he was sent back to Earth by the goddess Miru. Though she instructed Tekauae never to speak of what he had experienced, when he reentered his body and returned to life he told his friends what to expect in the other world (Savage, 1916, pp. 145146, 173-175).

According to a report from 1874, on Tuamotu island (Fangatau) it was believed that souls could leave the body during illness and travel to the other world. At the entrance they met the deity Tama "who tried to send them back to their bodies. If they persisted in going on, they found themselves definitely separated from their bodies" and had to remain in the otherworld (Williamson, 1933, vol. II, p. 81).

A Marquesan myth from Fatuhiva also parallels NDEs. When two 
deities took Taa-po as their wife, she died and her soul traveled to the spirit-world. The deities decided to send her back to Earth where she "entered into her body," revived, and told her joyful relatives of her experiences in the spirit world. When a chief questioned her story, Taa-po insisted that she had died but clarified that she was taken only "to the threshold" of the otherworld. In another narrative, a deified shaman took Tiki-tu-ao to the sky-realm where he saw his brother-inlaw who was undergoing an out-of-body journey while chanting in a ceremony on Earth. The encounter was premonitory, for the brotherin-law was killed soon after Tiki-tu-ao returned to Earth (Handy, 1930, pp. 82-84, 133-134, 137).

Samoans believed that if the soul of a recently dead person struck a certain tree in the underworld, it "went back at once to its body" (Turner, 1884, pp. 258-259). Samoan afterlife beliefs were "confirmed by . . . accounts of men going to the other world and returning again to this one." The soul was conceived as an immaterial duplicate of the body which could temporarily separate from it during unconsciousness (Brown, 1910, pp. 219-224, 364-365). In a brief narrative from 1902, a princess died, but her soul returned to her body after a visit to "the ninefold heaven" (Beckwith, 1940/1970, p. 150).

Narratives of individuals visiting the afterlife realm of Pulotu were "fairly common" in Tonga (Gifford, 1924, p. 153). In one myth, Tui Hattala instructed his people not to bury his body. He then traveled in spirit form to the underworld of Pulotu and met the deity Hikuleo, who told him that he must return to Earth because he had visited Pulotu before his death. When Tui Hattala did so, however, he discovered that, against his instructions, his body had been buried, and he thus had to remain in spirit form (Gifford, 1924, pp. 153-155).

In New Zealand, the Maori believed that souls of the dead crossed the underworld river on a plank. A deity either assisted them or drove them back to their bodies "in order that he may take care of the family he has left behind" (Taylor, 1855, pp. 104-105). Citing beliefs that "in illness the soul journeys away and is sometimes on the brink of crossing to Hades, but returns," Edward Tregear (1890, pp. 118-119) concluded that narratives about the otherworld originated in "the dreams of people in trance through illness." Similarly, Elsdon Best (1905) wrote that Maori afterlife beliefs were "the result of persons dreaming of having descended to the underworld . . . A person recovering from a trance would be said by the Maori to have returned from the spirit-world" (pp. 231-232).

The Maori also believed that the living could travel temporarily to 
the spirit world of Reigna by leaping off a precipice called Te Rerenga Wairua (Dieffenbach, 1843, pp. 66-67). It "often" happened "that persons who have died, and actually descended this precipice, have returned again to earth to relate what they had seen below, and lived for many years afterwards" (Shortland, 1856, p. 150). There were "many stories of persons who have descended into the Reigna and returned" (Taylor, 1855, pp. 105-106). According to shamans, when souls arrived at Te Rerenga Wairua they were questioned about their identity and occupation on Earth. The soul "replied by giving a history of its life" before proceeding to a river crossing. Some were refused passage, however, and were "sent back to life." Such beliefs explained recoveries "from insensibility caused by a blow, or fit, or trance" (White, 1891, pp. 145-146). A recently deceased person could also return to life when his or her soul was sent back from the netherworld "by its relatives, for the purpose of caring for its children" (Goldie, 1904, p. 20).

One man recounted the NDE of his aunt, who revived a day or two after her death and described her out-of-body experience (OBE) journey to Te Rerenga Wairua. She descended on a vine, and an old man ferried her across a river, then led her to her family. Her father instructed her to "go back to earth, for there is no one now to take care of my grandchild." He warned her not to eat anything in Reigna, ferried her back across the river, and told her to hurry. As she struggled up the precipice "two infant spirits" tried to drag her back, but when she threw sweet potatoes they leapt after them. She then "flew back to the place where she had left her body," revived, and realized "that she had really died, and had returned to life." "Those who listened to her tale believed firmly the truth of her adventures" (Shortland, 1856, pp. 150-155).

The NDE of Te Atarahi was reported by various scholars and missionaries (Shortland, 1882, p. 45; Taylor, 1855, pp. 104-105; Tregear, 1890, pp. 118-119), demonstrating consistency over time and lasting local significance. Te Atarahi died and travelled to Reigna where he met deceased relatives who told him not to eat anything. They sent him back to Earth five days later, and when he returned to his body he described his visit to the wonderful otherworld.

In a rare shared-death experience (cf. Moody 2010), two men died, revived, and told of how their souls had descended a cliff then climbed over a wall to the spirit land- "a very good sort of place" similar to Earth. They found their people, including their parents who sent them back to their bodies (Best, 1905, p. 231). In a brief account, a woman 
was "carried off by spirits . . . and she saw the spirits of all the deadand-gone people ere she returned here" (Best, 1900, p. 232).

An early 1960s Maori NDE should also be noted. A woman named Nga revived as her body was being taken for burial. She described an OBE in which her soul hovered above her head before exiting the room and proceeding to Te Rerenga Wairua. After bathing in a spring she prepared to slide down to the underworld on a root of a tree, but a voice stopped her, asking her identity and her purpose there. She replied that she sought her "old people," but the voice told her, "They don't want you yet. Eat nothing and go back where you came from until they are ready. Then I shall send for you." She obeyed and returned to her body (King, 1985, pp. 87-88; cf. Kellehear, 2001; Tassell-Matamua, 2013, p. 113).

Maori afterlife myths also featured NDE and shamanic journey experience elements. One told of how the deity Tane followed his daughter to the underworld hoping to bring her back, though she told him to return to Earth in order to raise their children. In another version, the woman was sent back from the underworld after being questioned by the "daughter of the light" (Taylor, 1855, pp. 131-132, 146).

\section{Micronesia}

Evidence for knowledge of NDEs in Micronesia is scant, though this rarity may be due to the fact that the islands saw far less extensive fieldwork than did other parts of Oceania (Dobbin \& Hezel, 2011, p. 13). On Waqab (Yap) in the Caroline Islands it was believed that during illness the soul was trying to escape and that it "may or may not be enticed to return." Epileptic seizures were thought to result when a returning soul collided with the body after wandering on the winds (Furness, 1910, pp. 147-151). Though there were occasional myths involving otherworld journeys (see Frazer, 1924, pp. 196-197, 201-202), they lack near-death or even OBE contexts and share little with NDE phenomenology. A Palau Islands myth concerns the goddess Milad returning from the dead, though it lacks details of any otherworld experience (Parmentier, 1987, p. 159).

Notable exceptions are the late 20th century NDEs of three Chamorra women in Guam. Though the Chamorro are primarily Catholic and have had long-term influence from Spain, the Philippines, and Mexico (Dobbin \& Hezel, 2011, p. 12), the NDEs feature some elements typical of small-scale societies, such as walking along a road, 
and spirit journeys to Earthly locales. Rather than islands or volcanoes, however, the NDErs visited family members in the United States. Additional elements include a paradisiacal realm, deceased relatives, encountering a spiritual being, being told to return (one on the grounds of mistaken identity, another being "not ready to enter"), and reluctance to return (Green, 1984).

\section{Melanesia}

Various Melanesian religious movements had foundations in NDEtype narratives. In a New Guinea legend recorded in 1854, Manarmakeri followed a pig to a beautiful otherworld village where his people sang and danced in the prime of youth. Manarmakeri wanted to stay, but a voice told him that his "time has not come yet" because he was "still in the husk." After returning to Earth he fell into a listless depression, though he ultimately became a religious leader, preaching resurrection, immortality, non-violence, and a return to a golden age state called Koreri. The narrative was considered historical fact and became the basis for further religious movements. In 1932, a Wandamen man was found alive three days after drowning. After describing his visit to the underworld where he met the dead, he became a medium and prophet and the founder of the Sade Koreri movement (Kamma, 1954/1972, pp. 23-26, 40, 65, 76-77, 278-279).

In 1919 at Orokolo Bay, a man named Ua Halai was dying from an illness. He instructed his people not to dig his grave and not to approach his body too closely but, rather, to "wait and see what they would see." Though the local people claimed that "Ua Halai was so 'dead' that the rats had gnawed his ears," he revived after three days and claimed that he had been to the other world where he was given moral strictures against theft and adultery. He became a leader of the so-called "Vailala Madness" religious movement and built temples for spirit mediumship (Williams, 1934, pp. 374-375).

In 1935 in the Markham Valley, a man named Marafi founded an apocalyptic, anti-mission movement after claiming that Satan "had taken him into the bowels of the earth, where he had seen the spirits of the dead who dwelt there." Marafi taught that Satan would allow spirits to return to Earth if the people accepted him as "the Supreme Being." On Karkar Island in 1949, a local cult was reinvigorated following the NDE of the prophet Kaum. He claimed that he had been killed and had gone to Heaven where he met God, saw deceased ancestors "making Cargo," and was given a new ritual symbol. On Buka 
Island around 1932, a prophet named Pako returned from the dead after being hanged. Another prophet of his cult was "said to have gone to Heaven where Saint Peter told him that people were to go to church regularly, to abandon their old dances and rituals, and to levy tolls and demand higher wages from the Whites." The Fijian Tuka cult was founded by a man named Kelevi who "claimed to have visited Heaven and to have supernatural powers" (Worsley, 1968, pp. 30, 101-102, $115,118,215)$.

In a brief account from Biak island, a dying man "dreamt of a golden ladder which took him up to the heavenly house" (Codrington, 1891, p. 102). Biak myths of "the resuscitation of dead persons through the love of their relatives" were intended as explanations of local afterlife beliefs (Kamma, 1954/1972, pp. 73-75).

On the Tami Islands, information about the afterlife was obtained by women who could "go down alive into the netherworld and prosecute their enquiries at first hand among the ghosts" (Frazer, 1913, pp. 291-292). On Misima Island, it was "not uncommon" for the souls of "living men and women to journey to Hiyoyoa [the otherworld] and return to this world," and most people "fully believed in the truthfulness of those who asserted that they had." A man named Tokeri visited Hiyoyoa and obtained prophetic information about an impending tsunami. Another man, Wakuri, traveled there many times through the use of a certain "medicine." He even claimed to have a wife and child there, though he never ate anything, for doing so would make him unable to return to Earth. In contrast, at Tubetube, a man named Maritaiyedi claimed that despite having dined with the spirits he was able to return from his numerous visits to the Earthly otherworld of Beswebo.

In northern Massim, various people claimed to have visited an idealized Earth-like afterlife realm beneath the island of Tuma. During an illness, the soul of a man named Marogus went there and met the deity Topileta, "who ultimately sent him back to the upper world." In a legend of the Koita people of Port Moresby, a man died and returned to his body, though it had already begun to decay. His wife refused to wash him, and had she done so, other souls would be able to return to their bodies after death (Seligman, 1910, pp. 189-191, 654-657, 733-734).

Many Kiwai narratives concern people who visited the otherworld of Adiri and returned (Landtman, 1912, pp. 71-72). A woman named Amara died from an illness "and subsequently returned to life." She described having traveled on a road and through clashing iron bars to 
a realm of abundance. She met other spirits, including her husband who asked the "big man" of Adiri if Amara could stay. She was allowed one day of dancing and festivities before being told that her time on Earth was not yet finished and that she must return. Her husband warned her not to eat anything, then gave her a shove which propelled her back into her body. She surprised the mourners when she revived, for she had been dead a long time. She told them about life in Adiri and "kept on telling" them.

A man named Asai likewise "died, returned to life and told his fellow villagers about Adiri." He traveled there by canoe and was greeted by his father and friends, dancing, singing, and drumming. Asai enjoyed it so much that he decided he wanted to stay. Sido, the first man to die, offered him a wife, but Asai was so taken with his surroundings that he ignored the girl, and Sido kicked him back into his body. When Asai awoke, his mourners told him that he had been dead since the previous day. In a related narrative, Asai died and his spirit traveled westward, but he decided to return to his body when he thought of his wife and child. Before doing so, he made a mark on a tree so he could later prove his story. He told his people that he had not seen any other spirits and that he did not know what happens when someone dies. They concluded that Asai had only traveled on the path towards Adiri and not to the realm itself. Because Asai now knew the road, he was no longer afraid of death (Landtman, 1912, pp. 72-73).

When a man named Duobe was injured in an accident, his spirit went to the otherworld where he met "dead people who were making a garden." Seeing that he was not dead, they asked him why he was there, and Duobe replied that he only wanted to look at them. His NDE then assumed distressing NDE features (cf. Bush 2009): A halfhuman/half-pig asked if wanted to look like him, and when Duobe replied that he did not, the man's pig nose fell off exposing a bare skull beneath. Duobe fled home in a canoe before the man could kill him. "Just as his spirit was entering his body he woke up shrieking," terrifying his wife. He said he had been to "devil-place" (Landtmann, 1917, pp. 170-171).

In another legend, a man named Ânai fell through a hole at his brother's grave. After four days they reappeared together and told of how they had been to the land of the dead, which was similar to Earth but more populous. They brought back new medicines, a yam, and various agricultural techniques. One of the brothers said that as a result of his experience, "he would not be afraid when he was going 
to die." From such narratives, "some people concluded that the place of the dead was underneath the ground." In addition, there are many examples of Kiwai afterlife dreams that bear similarities to NDE accounts, as well as return-from-death narratives without descriptions of afterlife journeys, which serve to explain new rituals, beliefs, or abilities (Landtman, 1912, pp. 71-77, 187-188, 264, 343-344, 442, 569). Numerous accounts of contact with spirits of the dead described them as radiating light (Landtman, 1917, pp. 110, 167-168, 170-172, 181-191, 306, 313, 588).

In the Trobriand Islands, Tuma could be visited by the souls of "those who were almost dead, but returned to life again" with new information, songs, or precognitive knowledge of the death of a family member (Malinowksi, 1916/1928, pp. 154, 162). The Orokaiva believed that people could "die and come to life again." When souls saw friends and relatives in mourning, they were "so affected by compassion as to return; whereupon the corpse is reanimated" (Williams, 1930, p. 269). In the Wedau and Wamira areas it was also believed that those who died before their time were sent back to Earth (Newton, 1914, pp. 219-220).

In the Tanga Islands, those who revived from prolonged unconsciousness were "regarded as having been dead and refused admittance to the underworld." In one example, a man was revived by his wife and described "what he believed to be his post mortem emotions and experiences." He was taken by a whirlwind to the land of the dead where he met his deceased grandmother. She told him that he was too young to remain there and "to go back to his family and his garden." Afterlife beliefs reportedly derived from such experiences (Bell, 1937, pp. 317-318, 337-338).

In a report from the Nggela Islands, a man "appeared to die, but revived to tell the story of how he had passed with others along the path of ghosts, and had come to take his place in the canoe which came for them at night." A spirit he recognized "forbad him to come aboard, and sent him back into the world again" (Codrington, 1891, p. 256). On Alu Island, it was believed that those who revived from illnesses had been sent back to the body following assessment in the otherworld. Shamans could undertake OBE journeys, and afterlife myths contained NDE features (Wheeler, 1914, pp. 87, 98ff, 111). On Makira, shamanic healers undertook trance-journeys to the other world to retrieve souls, including those who were unwilling to return (Beckwith, 1940/1970, p. 150). 


\section{On the Banks Islands of Vanuatu it was accepted that}

at times a departed soul has come back from the sura [entrance to the other world] to his body; and the man has revived to tell how he was hustled out of the sura by the ghosts, who said there was no room for him, and he must go back.

Reports of such journeys were "by no means uncommon." Afterlife conceptions derived from them, and were sometimes validated through shamanic experiences (Codrington, 1881, p. 283). Upon arrival at sura, souls were asked if they were there to stay, and those who were merely unconscious were sent back to their bodies. Deceased friends or relatives would explain that "his time has not yet come; so he relates when he returns." On Pentecost Island, when a person lost consciousness then revived "he says he was not allowed to enter" Panoi. On Maewo it was believed that the soul encountered "the stone of thought" on the journey to the other world. If a man "remembers there his child or his wife or anything that belongs to him, he will run back and come to life again." He will also return if he fails to clear a certain ravine. The belief that shamans could visit the otherworld in order to rescue souls was common (Codrington, 1891, p. 208-209, 266-267, 274-275, 287; cf. Beckwith, 1940/1970, p. 172). On Malekula it was believed that "the sacred men have often been on a visit [to the otherworld], and consequently know all about it" (Somerville, 1894, p. 10). Afterlife myths in these islands often paralleled NDEs (e.g., Codrington, 1881, p. 283; Codrington, 1891, pp. 278, 286; Humphreys, 1926, pp. 97-98).

Soul-retrieval beliefs were also common on Fiji, as were narratives of OBE visits to the underworld (Williams, 1860, pp. 190-194). A deity named Taleya ("the Dismisser") "sifted out the real dead from the trance-smitten" and sent the latter back to life. Those who died naturally, as opposed to in battle or by drowning, were also told, "go back and re-enter your body." Some refused, however, for "so gloomy and joyless is the prospect of a return to life that the Shades who are offered the privilege by Taleya do not all obey" (Thomson, 1908, pp. 125, 132).

In a myth from the Lau Islands, the body of a man named Tui Liku washed up on the shore as his spirit accompanied the deity Ligadua to the otherworld. Because he followed the restrictions placed upon him during his visit, Tui Liku was able to return to Earth. On his return from a subsequent journey to the otherworld, Tui Liku was horrified to find that a bird had been pecking at his corpse and had removed one 
of his eyes. "I refuse to get into that," he cried, but Ligadua gave him no choice. The narrative was considered "a true story of what actually happened" (St. Johnston, 1918, pp. 19, 44-45).

In New Britain it was believed that "when a man dies his soul goes to the spirit-land and meets his friends there, but if they do not want him at that time, they all drive him away, and so he returns to life again." In one brief account, a man named Warulung "returned from the dead and brought messages to the people from departed spirits." Related practices included shamanic soul-retrieval as well as accompanying the soul to the otherworld in dreams and then returning with descriptions of it (Brown, 1910, pp. 190, 194, 398). Moss (1925) suggested that such practices were responsible for "certain conceptions of the afterlife" (pp. 120-121).

Three early 1980s Kaliai NDEs should also be mentioned. Though converted to Catholicism in 1949, the Kaliai have retained many indigenous traditions-particularly funerary beliefs. In the first NDE, a man named Frank died of an illness and met deceased ancestors who directed him to a road. He encountered a bearded, robed, whiteskinned being of light who motioned him to turn back. A man named Andrew also died of an illness and returned. He described an NDE in which he entered darkness and then emerged into a "field of flowers" and a realm of clarity. On a road he met "a woman whose death had occurred shortly after his and about which he could have had no knowledge." Arriving at a village, he climbed a ladder up to a house. A voice told him it was not his time to die and that he should wait for someone to take him back to Earth. As children assisted him down the ladder, he realized that the house was floating and rotating in the air. Inside, people were building cars and ships-reflecting "cargo cult" beliefs associating whites and their technology with the spirit realm. Again he was told it was not his time and to wait for a return guide, but he continued along a beam of light and down a flight of steps to a forest. He was then informed that if his people had begun mourning him, he would have to stay in the other world. The beam of light led him down a path, and he found himself back in his body. He was reluctant to return for he had felt happy in the other realm. The third Kaliai NDE similarly had common NDE elements alongside idiosyncratic features. A man named Luke described undergoing judgment on a pair of magnetic scales and then meeting deceased relatives who told him to return to Earth. When a woman with bloody eyes and lolling tongue tried to stab him, he ran away and found himself back in his body (Counts, 1983, pp. 115-116, 118, 119-121). 


\section{Australia}

There are a few brief Aboriginal accounts of "living people who have been to the Land of the Dead, voluntarily or otherwise." A Lower River Murray man revived on his funeral pyre and told of his visit to the home of the culture-hero Ngurunderi (Berndt \& Berndt, 1964, p. 417). A dying Gunaikurnai woman claimed "that she had gone up to the [sky-realm] in sleep, but returned because she could not get through." In a Gunaikurnai legend, a man traveled to the spirit land with the soul of his friend's gravely ill son and saw deceased relatives and friends (Howitt, 1904, pp. 434-437). The Gunwinggu believed that when souls traveled to the spirit world, a "powerful being" knocked out their middle teeth. "If the person is really dead, there is no blood," but if the gums bled, the spirit was sent back to the body, which then revived (Berndt \& Berndt, 1964, pp. 414-415).

Most Aboriginal otherworld journey accounts have shamanic contexts, however. In a Barkindji legend, a shaman named Barpoo visited the other world by eating a piece his recently deceased teacher's thigh. His "spirit flew away beyond the sky" and encountered a beautiful goddess who "showed him all the abundance of the joys prepared for his people" after death. Barpoo became a religious leader, and his people "believed he had actually visited their heaven" (Newland, 1887-88, p. 31). The Gunwinggu believed that shamans "can heal a sick person by following his spirit in a dream, catching it and returning it to his body" (Berndt \& Berndt, 1964, p. 258). Such experiences resulted in "a conception of the individual apart from the body, not only during life but also after death, as an immaterial, invisible being" (Howitt, 1887, p. 52).

Shamanic initiation practices were often linked thematically with NDEs, involving "symbolic death followed by resurrection." Initiates in trance states were mourned as if recently dead, and during "ecstatic experiences" would undertake "ascents to heaven and descents to the subterranean world." They returned transformed and "reborn," with new knowledge or abilities received from the "supernatural beings" they encountered (Eliade, 1973, pp. 130, 144-145). At Port Stephens initiates were "killed" in a fire, then emerged as "a new personality" who could travel to the sky-world in dreams, retrieve souls, and practice sorcery. At Ooldea, initiates were mourned while in trance, and their bones were broken. After conversing with spirits, they were reborn with supernatural powers. Initiates of the Djerag and Djaru peoples were "killed" by the rainbow-serpent, causing an illness and mad- 
ness that enabled them to ascend to the sky and visit the dead (Elkin, 1945, pp. 91-92, 112-114, 138). Aranda initiates traveled to the other world by being "killed" in a sacred cave by spirits who replaced their internal organs and inserted healing stones into their bodies. When the initiate "comes to life again" he "dwells upon his experiences" for a year while learning the shamanic craft (Howitt, 1904, pp. 391-392).

\section{Analysis and Conclusions: Cultural Dynamics in the Reception of NDEs}

Examples of afterlife beliefs being obtained or validated by people who had NDEs were found in both Polynesia and Melanesia. Beliefs that attest to knowledge of NDEs were widespread: Individuals who returned from apparent death had been sent back by spirits in the other world. Despite variations, afterlife beliefs largely corresponded to NDE phenomenology on a thematic level. The interaction of beliefs with experiences, alongside widespread knowledge of NDEs, also correlates with a greater number of afterlife myths. Beliefs in OBE visits to the otherworld in non-death contexts, such as dreams or trance, and in shamanic soul-retrieval, possession, trance mediumship, and deathbed visions were also found in both areas. Although detailed examples of shamanic experiences were scarce, quite a few narratives have shamanic themes or contexts, demonstrating a clear connection between shamanic and near-death experiences. All of these data indicate among Polynesian and Melanesian peoples a general receptivity to NDEs together with a high level of interest in afterlife-related phenomena. Yet, whereas Polynesian societies focused more acutely on otherworld journey experiences and myths, Melanesian societies seemed open to many different forms of spiritual experiences and had an intense interest in the afterlife.

There were few examples of Polynesian new religious movements with NDE foundations. A greater number were found in Melanesia, including the Vailala, Tuka, and Koreri. Such movements were legitimized, promoted, and sustained through their leaders' additional visits to the otherworld as well as through other kinds of visions, dreams, and prophecies (Worsley, 1968, pp. 20ff, 69ff, 103-104).

In both regions, funerary rituals allowed for the possibility of the soul returning to the body. In Hawai'i especially, great care was taken to avoid premature burial. Bodies were periodically checked for a heartbeat for a number of days prior to interment (Green \& Beck- 
with, 1926, p. 177). Practices were similar on Tahiti, and much effort was expended in keeping alive those in danger of death (Oliver, 1974, pp. 488, 496). Maori burial was performed at least three days after death (Frazer, 1922, p. 20), and efforts were made to restore souls of the recently dead to their bodies (Best, 1901, p. 10; Goldie, 1904, p. 20). This was also the case in Melanesia, on Mota Lava (Codrington, 1891, pp. 266-267). On Kiwai and in the Tanga Islands, bodies were not buried until decomposition (Landtman, 1917, p. 12; Bell, 1937, pp. 321-322). The Dobu of the D'Entrecasteaux Islands believed that otherworld spirits ensured that souls were truly dead by admitting only those whose bodies had begun to decay (Fortune, 1963, pp. 181-182).

Although such practices and beliefs likely facilitated the occurrence of NDEs, it is important not to overgeneralize. In New Guinea and on Fiji, individuals were buried alive if it was believed that they would not recover or if there was danger of witchcraft. It was also customary for the sick and elderly on Fiji and Mota to request that they be killed (Brown, 1910, pp. 391-392; Williams, 1860, p. 144). On Mota, they were sometimes buried alive (Codrington, 1880, p. 125). On the Banks Islands, a lack of both NDEs and detailed afterlife beliefs correlates with a fear of ghosts and graveyards, hasty burial practices, and attendees fleeing the gravesite as soon as the individual stopped breathing. If the dying process was prolonged, the person might request live burial (Humphreys, 1926, p. 166).

The diversity of Melanesian attitudes toward the afterlife is reflected in varying methods of corpse disposal, interest in both possession and otherworld journey experiences, and concern with both benevolent and malevolent spirits of the dead. There is also variation in Polynesia, including a report that the Maori rarely attempted to revive the dead and that the sick were often left alone to die (Tregear, 1890, pp. 119-120). In general, however, Polynesian attitudes appear to have been more homogeneous than Melanesian. This finding is unsurprising given Polynesia's greater overall cultural homogeneity in comparison to Melanesia's "hundreds" of ethnic groups (Oliver, 2002, p. 2).

Micronesia and Australia had an almost total lack of documentary NDEs, no indigenous statements that beliefs originated in them, and few afterlife journey myths. The reasons for these shared dynamics, however, are due to rather different cultural peculiarities.

Micronesian shamanism was focused on possession and trance mediumship rather than on soul travel or retrieval (Dobbin \& Hezel, 
2011, pp. 213-214; Frazer, 1924, p. 265). These practices effectively brought the dead to the living for purposes of divination, apparently obviating the need for the living to visit the dead. Even in the rare examples of NDE-like narratives, the deceased does not reenter the body upon returning to Earth but remains in spirit form (Goodenough, 2002, p. 150), reflecting a "Micronesia-wide" concern that the dead do not return except as benevolent spirits. Corpses were quickly disposed of to prevent their souls from returning to them, and large stones were placed on bodies to prevent them from rising (Dobbin \& Hezel, 2011, p. 79, 155, 215). Rather than NDEs generating afterlife beliefs, dreams and visions of spirits of the dead reinforced established beliefs. Nor did Micronesian religious revitalization movements have NDE foundations. Burial practices were also a factor. In the Gilbert Islands, they were designed to drive away the soul. In the Mortlock Islands, bodies were bound prior to burial, and in the Marshall Islands they were eviscerated immediately after death (Frazer, 1924, pp. 43-44, 90, 116-117, 171-172, 234-235, 265). Although afterlife journey narratives were almost entirely absent from all these regions, Yap Island is the Micronesian exception that proves the rule. Much effort was expended on reviving the dying, the dead were buried only after a number of days (Furness, 1910, pp. 163-164), and hasty burials were believed to carry a risk of misfortune (Frazer, 1924, pp. 171172). These practices - which encouraged revival both before and after apparent death-correspond to a greater number of afterlife journey narratives as well as soul travel and soul retrieval practices and beliefs, and a greater interest in the afterlife in general.

Though shamanic and near-death experiences often share similar phenomenological and transformative features (cf. Shushan, 2018), Australian accounts of otherworld journeys had primarily shamanic contexts. Although it is possible that otherworld journeying practices were attempts to reproduce NDEs, it may be that they were developed independent of knowledge of NDEs and naturally became the focus of afterlife knowledge. Rather than obtaining details about the otherworld or the fate of the soul (cf. Berndt \& Berndt, 1964, p. 278), the "fruits" resulting from the experiences were the primary reasons for undertaking them. A pragmatic, this-worldly orientation gave shamanism a focus on charms, healing, and divination. Indeed, the marked diversity of Aboriginal afterlife beliefs may be due to their being grounded in more culturally-constructed shamanic experiences rather than in spontaneous, evidently universal NDEs. The varied beliefs included reincarnation (Spencer \& Gillen, 1927, pp. 421-423, 
453), traveling west "to a large pit" (Eyre, 1845, p. 356), ascending to a sky-world, a continual process of cyclical birth and rebirth, and component souls that could simultaneously become a spirit on Earth, go the realm of the dead, merge "with the great ancestral and creative beings, and so on" (Berndt \& Berndt, 1964, pp. 204, 409, 419). The Murngin even had a myth explaining why people "stay dead and never come back to life." Unsurprisingly, their afterlife beliefs little resembled NDEs. Though one soul component went to the spirit world, the true self became a fish-like creature living in sacred emblems underwater. In a rare otherworld journey myth, the protagonist traveled there bodily and was killed by ghosts upon his return (Warner, 1937, pp. 445-446, 523-528).

As in Micronesia, the elderly who had become a burden were put to death. Corpses were regarded with fear (Berndt \& Berndt, 1964, p. 391) and were bound immediately after death then buried or cremated the next day. The arm and leg bones of chiefs were removed immediately for distribution to relatives (Dawson, 1881, p. 62). The Dieri took pains "to prevent the body from rising" by tying together the thumbs and the toes (Howitt, 1904, p. 449).

As one of the world's oldest continuous cultures, it would be surprising if NDEs were unknown to Aboriginal Australians. It may be that they were typically interpreted as shamanic phenomena-and reported as such - and that individuals were considered shamans by virtue of having had the experience, as in some North American societies (see Shushan, 2016, 2018). However, the almost total lack of return-from-death contexts in the shamanic narratives makes this conjecture overly speculative. The dearth of Australian and Micronesian NDEs is more likely related to the combination of preemptory funerary practices, a general lack of interest in the afterlife, and shamanic practices that had similar benefits to those resulting from NDEs.

It should be noted that a lack of common ancestry (see Friedlander et al., 2008) means that cultural diffusion cannot explain the greater similarities between Polynesia and Melanesia on the one hand, and Australia and Micronesia on the other. Polynesia actually shared greater ancestral links with Micronesia, whereas Melanesia had marginally greater links with Australia, despite the greater religio-cultural dissimilarities between these pairs of regions. The greater incidence of NDEs in Polynesia and Melanesia must therefore be due to incidentally similar cultural patterns, including receptivity to NDEs and funerary practices that facilitated their occurrence. 


\section{References}

Beckwith, M. (1970). Hawaiian mythology. Honolulu, HI: University of Hawai'i Press. (Original work published 1940)

Bell, F. L. S. (1937). Death in Tanga. Oceania, 7(3), 316-339.

Berndt, R. M., \& Berndt, C. H. (1964). The world of the first Australians. London, England, UK: Angus \& Robertson.

Best, E. (1900). Spiritual concepts of the Maori, Part I. Journal of the Polynesian Society, 9(4), 173-199.

Best, E. (1901). Spiritual concepts of the Maori, Part II. Journal of the Polynesian Society, 10(1), 1-20.

Best, E. (1905). Maori eschatology. Transactions and Proceedings of the New Zealand Institute, 38, 148-239.

Brown, G. (1910). Melanesians and Polynesians: Their life-histories described and compared. London, England, UK: Macmillan.

Bush, N. E. (2009). Distressing Western near-death experiences: Finding a way through the abyss. In J. M. Holden, B. Greyson, \& D. James (Eds.), The handbook of near-death experiences: Thirty years of investigation (pp. 63-86). Santa Barbara, CA: Praeger/ABC-CLIO.

Codrington, R. H. (1880). Notes on the customs of Mota, Banks Islands. Transactions of the Royal Society of Victoria, 16, 119-144.

Codrington, R. H. (1881). Religious practices and beliefs in Melanesia. Journal of the Anthropological Institute of Great Britain and Ireland, 10, 261-316.

Codrington, R. H. (1891). The Melanesians: Studies in their anthropology and folklore. Oxford, England, UK: Clarendon.

Counts, D. A. (1983). Near-death and out-of-body experiences in a Melanesian society. Anabiosis, 3, 115-135. doi:10.17514/JNDS-1983-3-2-p115-135.

Dawson, J. (1881). Australian aborigines. Melbourne, Australia: Robertson.

Dieffenbach, E. (1843). Travels in New Zealand. London, England, UK: Murray.

Dobbin, J., \& Hezel, F. X. (2011). Summoning the powers beyond: Traditional religions in Micronesia. Honolulu, HI: University of Hawai'i Press.

Eliade, M. (1973). Australian religions. Ithaca, NY: Cornell University Press.

Elkin, A. P. (1945). Aboriginal men of high degree. Sydney, Australia: Australian Publishing.

Ellis, W. (1917). A narrative of a tour through Hawaii. Honolulu, HI: Hawaiian Gazette. (Original work published 1823)

Emerson, J. S. (1902). Hawaiian beliefs regarding spirits. Ninth Annual Report of the Hawaiian Historical Society, 10-17.

Ernst, M., \& Anisi, A. (2016). The historical development of Christianity in Oceania. In L. Sanneh \& M. J. McClymond (Eds.), The Wiley Blackwell companion to world Christianity (pp. 588-604). Chichester, England, UK: Wiley Blackwell.

Eyre, E. J. (Ed.). (1845). Journals of expeditions of discovery into Central Australia (Vol. 2). London, England, UK: Boone.

Fornander, A. (1918-19). Collection of Hawaiian antiquities and folk-lore (2nd series). Honolulu, HI: Bishop Museum Press.

Fortune, R. F. (1963). Sorcerers of Dobu (2nd ed.). London, England, UK: Routledge and Kegan Paul. 
Frazer, J. G. (1913, 1922, 1924). The belief in immortality and the worship of the dead (vols. 1-3). London, England, UK: MacMillan.

Friedlaender, J. S., Friedlaender, F. R., Reed, F. A., Kidd, K. K., Kidd, J. R., Chamber, G. K., . . . Weber, J. L. (2008). The genetic structure of Pacific Islanders. PLOS Genetics. Retrieved from https://journals.plos.org/plosgenetics/ article?id=10.1371/journal.pgen.0040019.

Furness, W. H. (1910). The island of stone money. Philadelphia, PA: Lippincott.

Gifford, W. W. (1924). Tongan myths and tales (Bulletin 8). Honolulu, HI: Bernice P. Bishop Museum.

Gill, W. W. (1876). Myths and songs from the South Pacific. London, England, UK: King.

Gill, W. W. (1877). On the origin of the South Sea Islanders, and on some traditions of the Hervey Islands. Journal of the Anthropological Institute, 6, 2-5.

Goldie, W. H. (1904). Maori medical lore. Transactions and Proceedings of the Royal Society of New Zealand, 37, 1-120.

Goodenough, W. H. (2002). Under heaven's brow: Pre-Christian religious tradition in Chuuk. Philadelphia, PA: American Philosophical Society.

Green, J. T. (1984). Near-death experience in a Chammorro culture. Vital Signs, $4(1 / 2), 6-7$.

Green, L. C., \& Beckwith, M. W. (1926). Hawaiian customs and beliefs relating to sickness and death. American Anthropologist, 28(1), 176-208.

Gunson, N. (1962). An account of the Mamaia or visionary heresy of Tahiti, 1826- 1841. Journal of the Polynesian Society, 7(2), 208-243.

Haley, E. N. (1907). A visit to the spirit land; or, The strange experience of a woman in Kona, Hawaii. In T. G. Thrum (Ed.), Hawaiian folk tales (pp. 5861). Chicago, IL: McClurg. (Original work published 1892)

Handy, E. S. (1927). Polynesian religion. Honolulu, HI: Bernice P. Bishop Museum. Handy, E. S. (1930). Marquesan legends. Honolulu, HI: Bernice P. Bishop Museum.

Henry, T. (Ed.), \& Orsmond, J. M. (1971). Ancient Tahiti. New York, NY: Kraus Reprint. (Original work published 1928)

Howitt, A. W. (1887). On Australian medicine men; or, Doctors and wizards of some Australian tribes. Journal of the Anthropological Institute of Great Britain and Ireland, 16, 23-59.

Howitt, A. W. (1904). The native tribes of southeast Australia. London, England, UK: Macmillan.

Humphreys, C. B. (1926). The Southern New Hebrides. Cambridge, England, UK: Cambridge University Press.

Jarves, J. J. (1843). History of the Hawaiian or Sandwich Islands. Boston, MA: Munroe.

Kalakaua, D. (1888). Legends and myths of Hawaii. New York, NY: Webster.

Kamakau, S. M. (1964). In D. Barrére (Ed.) \& M. K. Pukui (Trans.), Ka Po'e Kahiko: The People of Old. Honolulu, HI: Bishop Museum Press. (Original work published 1866-71)

Kamma, F. C. (1972). In W. E. Haver Droeze-Hulswit (Ed.) \& M. J. van da Vathorst-Smit (Trans.), Koreri: Messianic movements in the Biak-Numfor culture area. The Hague, Netherlands: Nijhoff. (Original work published 1954)

Keauokalini, Z. K. (1932) In M. W. Beckwith (Trans.), Kepelino's traditions of Hawaii (Bulletin 95). Honolulu, HI: Bernice P. Bishop Museum. (Original work published 1860) 
Kellehear, A. (2001). An Hawaiian near-death experience. Journal of NearDeath Studies, 20, 31-35. doi:10.17514/JNDS-2001-20-1-p31-35.

King, M. (1985). Being Pakeha: An encounter with New Zealand and the Maori renaissance. Auckland, New Zealand: Hodder and Stoughton.

Landtman, G. (1912). Wanderings of the dead in the folk-lore of the Kiwaispeaking Pauans. In O. Castrén, Y. Hirn, R. Lagerborg, \& A. Wallensköld (Eds.), Festskrift Tillengnad Edvard Westermarck $i$ Anledning av Hans Femtioårsdag den 20 November 1912, 5980. Helsingfors, Finland: Simelii.

Landtman, G. (1917). Folk-tales of the Kiwai Papuans (Acta Societatis Scientiarum Fennicae, 47). Helsingfors, Finland: Finnish Society for Literature.

Malinowski, B. (1928). Baloma: The spirits of the dead in the Trobriand Islands. London, England, UK: Faber \& West. (Original work published 1916)

Moody, R. (2010). Glimpses of eternity. Harlan, IA: Guideposts.

Moss, R. (1925). The life after death in Oceania and the Malay Archipelago. Oxford, England, UK: Oxford University Press.

Newland, S. (1887-88). The Parkengees, or Aboriginal tribes on the Darling River. Papers Read before the Royal Geographical Society of Australia, South Australian Branch, 3rd Session, 20-32.

Newton, H. (1914). In far New Guinea. London, England, UK: Seely, Service.

Oliver, D. L. (1974). Ancient Tahitian society (Vols. 1-3). Honolulu, HI: University of Hawai'i Press.

Oliver, D. L. (1989). Oceania: The native cultures of Australia and the Pacific Islands (Vol. 1). Honolulu, HI: University of Hawai'i Press.

Oliver, D. L. (2002). Polynesia in early historic times. Honolulu, HI: Bess.

Parmentier, R. J. (1987). The sacred remains: Myth, history and polity in Belau. Chicago, IL: University of Chicago Press.

Rice, W. H. (1923). Hawaiian legends (Bulletin 3). Honolulu, HI: Bernice P. Bishop Museum.

Savage, S. (1916). The period of Iro-nui-ma-oata and Tangiia-nui-ariki. Journal of the Polynesian Society, 25(100), 138-149.

Seligman, C. G. (1910). The Melanesians of British New Guinea. Cambridge, England, UK: Cambridge University Press.

Shortland, E. (1882). Maori religion and mythology. London, England, UK: Longman Brown Green.

Shortland, E. (1856). Traditions and superstitions of the New Zealanders (2nd ed.). London, England, UK: Longman.

Shushan, G. (2016). "The Sun told me I would be restored to life": Native American near-death experiences, shamanism, and religious revitalization movements. Journal of Near-Death Studies, 34, 127-150. doi:10.17514/JNDS2016-34-3-p127-150.

Shushan, G. (2018). Near-death experience in indigenous religions. New York, NY: Oxford University Press.

Somerville, B. T. (1894). Notes on some Islands of the New Hebrides. Journal of the Anthropological Institute of Great Britain and Ireland, 23, 2-21.

Spencer, B., \& Gillen, F. J. (1927). The Arunta: A study of a Stone Age people. London, England, UK: Macmillan.

Stevenson, R. L. (1896). In the South Seas. New York, NY: Scribner's. (Original work published 1891) 
St. Johnston, T. R. (1918). The Lau Islands (Fiji) and their fairy tales and folklore. London, England, UK: Times.

Tassell-Matamua, N. (2013). Phenomenology of near- death experiences: An analysis of a Maori case study. Journal of Near-Death Studies, 32, 107-117. doi:10.17514/JNDS-2013-32-2-p107-117.

Taylor, R. (1855). Te Ika a Maui, or New Zealand and its inhabitants. London, England, UK: Wertheim \& Macintosh.

Thomson, B. (1908). The Fijians: A study of the decay of custom. London, England, UK: Heinemann.

Tregear, E. (1890). The Maoris of New Zealand. Journal of the Anthropological Institute of Great Britain and Ireland, 19, 96-123.

Turner, G. (1884). Samoa, a hundred years ago and long before. London, England, UK: Macmillan.

Warner, W. L. (1937). Black civilization. New York, NY: Harper.

Westervelt, W. D. (1915). Legends of gods and ghosts. Boston, MA: Ellis.

Wheeler, G. C. (1914). An account of the death rites and eschatology of the people of the Bougainville Strait (Western Solomon Islands). Archiv für Religionswissenschaft, 17, 64-112.

White, J. (1891). A chapter from Maori mythology. Report of the Third Meeting of the Australasian Association for the Advancement of Science, 3 (pp. 359-364). Sydney, Australia: The Association.

Williams, F. E. (1930). Orokaiva society. London, England, UK: Oxford University Press.

Williams, F. E. (1934). The Vailala Madness in retrospect. In E. E. EvansPritchard, R. Firth, B. Malinowski, \& I. Schapera (Eds.), Essays presented to C. G. Seligman (pp. 369-380). London, England, UK: Kegan Paul.

Williams, T. (1860). Fiji and the Fijians (Vol. 1). New York, NY: Appleton.

Williamson, R. W. (1933). Religious and cosmic beliefs of Central Polynesia (Vols. I \& II). Cambridge, England, UK: Cambridge University Press.

Worsley, P. (1968). The trumpet shall sound (2nd ed.). New York, NY: Schocken. 